\title{
PENERAPAN MODEL DISCOVERY LEARNING DALAM PEMBELAJARAN IPA TEMATIK DI SEKOLAH DASAR
}

\author{
Nelvianti, Widya Indra, Rauladety Anas, Yanti Fitria, Desyandri \\ Surel: nelviant4@gmail.com
}

\begin{abstract}
This study aims to provide an overview of the application of discovery learning models in thematic science learning in State Elementary School 01 Pakan Rabaa, Solok Selatan Regency. The background of this research is the importance of teachers knowing the steps in applying discovery learning models in thematic science learning in order to create science learning that is not only oriented towards results or products but also processes. This research uses a qualitative approach with descriptive methods. Data on teacher opinions were collected through interviews. Data in the form of interviews, observations and documentation were analyzed descriptively. Data analysis is performed through data collection, reduction, presentation and conclusion drawing. The subjects of this study were the teachers of State Elementary School 01 Pakan Rabaa, Solok Selatan Regency. Based on the results of data analysis, it was found that thematic science learning with discovery learning models can involve students to develop knowledge and skills in solving problems, so that by applying discovery learning models can make students who are initially passive become more active and creative.
\end{abstract}

Keywords: Discovery learning model, thematic science, elementary school

\begin{abstract}
ABSTRAK
Penelitian ini bertujuan untuk memberikan gambaran tentang penerapan model discovery learning dalam pembelajaran IPA tematik di Sekolah Dasar (SD) Negeri 01 Pakan Rabaa Kabupaten Solok Selatan. Yang melatar belakangi penelitian ini adalah pentingnya guru mengetahui langkah-langkah penerapan model discovery learning dalam pembalajaran IPA tematik guna menciptakan pembelajaran IPA yang tidak hanya berorientasi pada hasil atau produk tetapi juga proses. Penelitian ini menggunakan pendekatan kualitatif dengan metode deskriptif. Data pendapat guru dikumpulkan melalui wawancara. Data berupa hasil wawancara, observasi dan dokumentasi dianalisis secara deskriptif. Analisis data dilakukan melalui pengumpulan data, reduksi, penyajian dan penarikan kesimpulan. Subjek dari penelitian ini adalah guru SD Negeri 01 Pakan Rabaa Kabupaten Solok Selatan. Berdasarkan hasil analisis data, ditemukan bahwa pembelajaran IPA tematik dengan model discovery learning dapat melibatkan peserta didik untuk mengembangkan pengetahuan dan keterampilan dalam memecahkan suatu permasalahan, sehingga dengan penerapan model discovery learning dapat membuat peserta didik yang awalnya pasif menjadi lebih aktif dan kreatif.
\end{abstract}

Kata kunci: Model discovery learning, IPA tematik, SD.

\section{PENDAHULUAN}

Hal yang tidak kalah penting dalam pembelajaran selain hasilnya adalah proses pembelajaran itu sendiri. Terlebih dalam pembelajaran IPA tematik di SD. Sejak diberlakukannya Kurikulum 2013 (K13), pembelajaran IPA di SD tidak 
lagi berdiri sendiri atau terpisah dari mata pelajaran lainnya. Namun demikian, diharapkan hakikat dari pembelajaran IPA tidak luntur. Hakikat pembelajarn IPA di SD adalah kumpulan produk ilmiah dan serangkaian proses ilmiah (Fitria, 2019).

IPA sebagai produk merupakan kumpulan pengetahuan yang didapat dari proses mencari penjelasan tentang gejala-gejala alam atau proses ilmiah. IPA sebagai proses yakni langkah-langkah yang ditempuh oleh para ilmuan dalam mencari penjelasan tentang gejala alam tersebut. Dan pada dasarnya, IPA sebagai produk dan IPA sebagai proses tidak bisa dipisahkan. Dengan artian, dalam pembelajaran kedua hal tersebut harus terlaksana secara simultan.

Sementara selama ini pembelajaran IPA hanya berorientasi pada produk (Tias, 2017).

Berdasarkan hasil observasi lapangan yang penulis lakukan di salah satu Sekolah Dasar (SD) di Kabupaten Solok, ditemukan bahwa pembelajaran IPA tematik di SD diajarkan tanpa mempertimbangkan model pembelajaran yang tepat. Pembelajaran hanya berfokus pada ketercapaian Kompetensi Dasar (KD) yang harus diselesaikan dalam waktu singkat, sebab masih ada mata pelajaran yang ingin diajarkan dalam suatu tema, sehingga hakikat pembelajaran IPA tidak terlaksana seutuhnya.

Padahal semestinya
pembelajaran tematik tidak menjadi alasan pembelajaran IPA diajarkan tidak secara mendalam, hanya menyentuh kulit luarnya saja dan tanpa menggunakan model pembelajaran yang cocok. Justru dengan adanya pembelajaran tematik, pembelajaran IPA dapat menjadi lebih baik dari sebelumnya dalam artian pembelajaran menjadi lebih bermakna.

Sebagaimana definisi

pembelajaran tematik yaitu, pembelajaran yang diawali oleh suatu tema tertentu yang menghubungkan dengan pokok bahasan lain, konsep tertentu dikaitkan dengan konsep lain yang dilakukan tanpa direncanakan atau direncanakan, baik dalam satu bidang studi atau lebih dan dengan beragam pengalaman belajar sehingga pembelajaran menjadi semakin bermakna (Fitria, 2019). Dinilai bermakna karena pembelajaran IPA tematik meningkatkan transfer ilmu yang dekat dengan kondisi nyata. Sementara pembelajaran yang menyajikan mata pelajaran secara terpisah kurang mengembangkan kemampuan peserta didik untuk berpikir secara holistik atau menyeluruh sehingga peserta didik akan kesulitan untuk memperoleh pengalaman bermakna. Pemaknaan terhadap pembelajaran IPA tematik ini urgen dikuasai oleh seorang guru.

Lebih lanjut (Fitria, 2019) menjelaskan bahwa, pembelajaran IPA tematik lebih menguntungkan peserta didik. Ditelisik lebih jauh, ketika peserta didik berhadapan dengan gagasan-gagasan yang berkaitan satu dengan yang lainnya, 
di situ terjadi retensi pada peserta didik.

Dalam pembelajaran tematik berpedoman pada beberapa landasan, diantaranya landasan normatif dan praktis yang menginginkan pembelajaran tematik dilaksanakan berdasarkan gambaran ideal yang ingin dicapai oleh tujuan pembelajaran dan memperhatikan situasi dan kondisi praktis sehingga pelaksanaannya berjalan optimal (Fitria, 2019). Berkaca dari hal ini, untuk mencapai pembelajaran IPA tematik yang optimal, guru mesti memperhatikan situasi dan kondisi. Situasi dan kondisi tersebut dapat dilihat dari sudut pandang model pembelajaran yang digunakan dan karakter peserta didik. Rancangan pengajaran di sini adalah memilih model pembelajaran yang tepat.

Bermain sambil belajar, yakni melaksanakannya saat proses pembelajaran. Maka dari itu, perlu bagi guru memilih model pembelajaran yang tepat, yang mana peserta didik merasa sedang bermain dalam mengikuti setiap langkahlangkah-langkah model pembelajaran yang dipilih guru.

Discovery learning adalah
belajar aktif di mana siswa
berpartisipasi secara aktif dalam
proses pembelajaran, tidak hanya
menerima secara pasif pengetahuan
seolah-olah mereka adalah kapal
kosong yang harus diisi oleh guru
(Brown \& Oakville, 2016).

Model Discovery learning merupakan model pembelajaran dimana pembelajaran terjadi jika peserta didik dapat mengorganisasikan sendiri tanpa diberikan pembelajaran dalam bentuk finalnya. Peserta didik diberikan kesempatan untuk menjelajah, menemukan, dan menyelesaikan sendiri jawaban-jawaban yang terjadi di dalam pembelajaran (Desyandri, Muhammadi, Mansurdin, \& Fahmi, 2019).

Hal ini sejalan dengan pendapat (Burais, Ikhsan, \& Duskri, 2016) yang menyatakan bahwa, model discovery learning yaitu suatu kegiatan pembelajaran yang terjadi apabila peserta didik tidak diberikan pembelajaran dalam bentuk utuhnya, akan tetapi peserta didik harus mengorganisasikan untuk sendiri pengetahuannya.

Model pembelajaran discovery melibatkan siswa untuk melakukan penyelidikan (Hammer, 2009). Dalam discovery learning keaktifan siswa sangat dituntut, siswa dibiarkan untuk mengkonstruk pemahamannya sendiri, sementara keikutsertaan guru tidak dominan. Dalam model ini guru hanya sebagai fasilitator (Kristin, 2016).

Model discovery learning dianggap sebagai model yang menuntut siswa untuk mengorganisasikan pembelajaran sendiri. Penggunaan model discovery learning, ingin merubah kondisi belajar yang pasif menjadi aktif dan kreatif. Mengubah pembelajaran yang teacher oriented ke student oriented. Mengubah modus ekspositori siswa hanya menerima informasi secara keseluruhan dari guru ke modus 
discovery siswa menemukan sendiri. Dengan mengaplikasikan model discovery learning secara berulangulang dapet meningkatkan kemampuan penemuan diri individu yang bersangkutan (Darmadi, 2017).

Berdasarkan teori di atas, penulis menyimpulkan bahwa model discovery learning adalah suatu kegiatan pembelajaran yang melibatkan peserta didik untuk mengembangkan pengetahuan dan keterampilan dalam memecahkan suatu permasalahan, sehingga dengan penerapan model discovery learning dapat membuat peserta didik yang awalnya pasif menjadi lebih aktif dan kreatif.

Melihat beberapa kelebihan model discovery learning di atas, maka model tersebut dinilai cocok sebagai salah satu model yang mestinya diterapkan dalam pembelajaran IPA tematik di SD.

SDN 01 Pakan Rabaa Kabupaten Solok Selatan merupakan salah satu sekolah yang sudah mengaplikasikan model discovery learning dalam pembelajaran IPA tematik.

Berdasarkan penjelasan di atas, penulis ingin mendeskripsikan penerapan model discovery learning dalam pembelajaran IPA tematik di SD.

\section{METODE PENELITIAN}

Penelitian ini yaitu penelitian deskriptif sebab hasil penelitian memaparkan informasi-informasi hasil analisis penerapan model discovery learning dalam pembelajaran IPA temarik di Sekolah Dasar (SD).

Penelitian dilaksanakan di SDN 01 Pakan Rabaa Kabupaten Solok Selatan. Adapun subjek yang diteliti yakni kepala sekolah dan guru di SDN 01 Pakan Rabaa Kabupaten Solok Selatan. Teknik pengumpulan data dilakukan dengan cara wawancara, observasi dan studi dokumentasi. Data berupa hasil wawancara mengenai penerapan model discovery learning dalam pembelajaran IPA tematik di SD, observasi dan dokumentasi dianalisis secara deskriptif. Analisis dimulai dari pengumpulan data, kemudian direduksi dan disajikan serta ditarik kesimpulannya. Sementara keabsahan data diuji dengan triangulasi sumber dan teknik.

\section{HASIL PENELITIAN DAN PEMBAHASAN}

Hasil penelitian ini mendeskripsikan tentang penerapan model discovery learning dalam pembelajaran IPA tematik di SDN 01 Pakan Rabaa Kabupaten Solok Selatan.

Berdasarkan hasil wawancara yang dilakukan dengan kepala sekolah dan guru di SDN 01 Pakan Rabaa mengenai langkah-langkah dalam penerapan discovery learning dalam pembelajaran IPA tematik didapat gambaran sebagai berikut. Langkah-langkah pembelajaran dengan menggunakan model discovery learning yaitu: Pertama, Stimulation (Pemberian Rangsangan). Peserta didik di stimulus dengan 
memberikan permasalah awal yang dapat membuat peserta didik untuk menyelidiki permasalahan tersebut. Guru sebagai fasilitator merangsang peserta didik dengan memberikan arahan, pertanyaan dan kegiatan pembelajaran yang terkait dengan model discovery learning.

Kedua, Problem Statement (Pernyataan/ Identifikasi Masalah). Pembelajaran pada langkah dengan memberikan kesempatan kepada peserta didik untuk mengidentifikasi kejadian-kejadian dari masalah yang sesuai dengan materi pembelajaran, kemudian peserta didik merumuskan permasalahan dalam bentuk hipotesis.

Ketiga, Data Collection (Pengumpulan Data). Langkah ini bertujuan untuk membuktikan pernyataan yang ada, sehingga peserta didik dapat mengumpulkan informasi dari sumber-sumber yang ada, mengamati objek masalah, wawancara dengan narasumber terkait masalah, dan melakukan uji coba mandiri.

Keempat, Data Processing (Pengolahan Data). Langkah ini merupakan suatu kegiatan mengolah data dan informasi yang sebelumnya telah didapat oleh peserta didik. Semua informai yang didapatkan semuanya diolah pada tingkat kepercayaan tertentu.

Kelima, Verification (Pembuktian). Langkah ini bertujuan untuk membuktikan benar atau tidaknya pernyataan yang sudah ada sebelumnya. yang sudah diketahui, dan dihubungkan dengan hasil data yang sudah ada.
Keenam, Generalization (Menarik Kesimpulan/ Generalisasi). Langkah ini merupakan proses kegiatan menarik sebuah kesimpulan yang akan dijadikan prinsip umum untuk semua masalah yang sama. Berdasarkan hasil ini, maka dirumuskanlah prinsip-prinsip yang mendasari generalisasi (Rohim \& Susanto, 2012).

\section{Pembahasan}

Adapun kelebihan pembelajaran dengan model discovery learning dapat membuat peserta didik aktif dalam pembelajaran, hal ini disebabkan karena peserta didik berfikir dan menggunakan kemampuannya untuk menemukan hasil akhir. Kepuasan batin ini mendorong peserta didik melakukan penemuan lagi sehingga minat belajarnya meningkat. Peserta didik yang memperoleh pengetahuan dengan penemuan akan lebih mampu mentransfer pengetahuannya ke berbagai konteks (Kristin \& Rahayu, 2016).

Pembelajaran discovery learning juga terdapat kendala yang dihadapi peserta didik, kendala ini menjadi kekurangan dalam pembelajaran discovery learning. Kendala yang dihadapi misalnya membutuhkan waktu belajar yang lebih lama dibandingkan dengan proses belajar menerima. Untuk mengurangi kelemahan tersebut maka diperlukan bantuan guru. Bantuan guru dapat dimulai dengan mengajukan beberapa pertanyaan dengan memberikan informasi secara 
singkat. Pertanyaan dan informasi tersebut dapat dimuat dalam lembar kerja siswa (LKS) yang telah dipersiapkan oleh guru sebelum pembelajaran dimulai.

\section{SIMPULAN}

Berdasarkan hasil analisis data yang dilakukan, maka dapat disimpulkan bahwa penerapan model discovery learning pada pembelajaran IPA tematik di SD membuat pembelajaran menjadi lebih bermakna. Hal ini disebabkan karena model pembelajaran discovery learning memberikan kesempatan kepada peserta didik untuk mencari, menemukan, dan memecahkan sendiri jawaban-jawaban yang terjadi di dalam pembelajaran.

\section{DAFTAR RUJUKAN}

Brown, E., \& Oakville, S. C. 2016. Discovery learning in the Classroom Emily Sandford Brown March 2006 Tell me and I will forget Show me and I may remember Involve me and I will.

Burais, L., Ikhsan, M., \& Duskri, M. 2016. Peningkatan Kemampuan Penalaran Matematis Siswa melalui Model Discovery learning. Peningkatan Kemampuan Penalaran Matematis Siswa Melalui Model Discovery learning, 3(1), 77-86.

Darmadi. 2017. Pengembangan Model dan Metode Pembelajaran dalam Dinamika Belajar Siswa. Yogyakarta: Deepublish.

Desyandri, D., Muhammadi, M., Mansurdin, M., \& Fahmi, R. 2019. Development of integrated thematic teaching material used discovery learning model in grade $V$ elementary school. Jurnal Konseling Dan Pendidikan, 7(1), 16.

Fitria, Y. 2019. Landasan Pembelajaran Sains Terintegrasi (Terpadu) untuk Level Dasar. Padang: Sukabina Press.

Hammer, D. 2009. Discovery learning and Discovery Teaching. Cognition and Instruction, 37-41.

Kristin, F., \& Rahayu, D. 2016. Pengaruh Penerapan Model Pembelajaran Discovery learning Terhadap Hasil Belajar Ips Pada Siswa Kelas 4 Sd. Scholaria: Jurnal Pendidikan Dan Kebudayaan, 6(1), 84.

Rohim, F., \& Susanto, H. 2012. Penerapan Model Discovery Terbimbing Pada Pembelajaran Fisika Untuk Meningkatkan Kemampuan Berpikir Kreatif. UPEJ (Unnes Physics Education Journal), 1(1).

Tias, I. W. U. 2017. Penerapan Model Penemuan Terbimbing Untuk Meningkatkan Hasil Belajar Ipa Siswa Sekolah Dasar. DWIJA CENDEKIA: Jurnal Riset Pedagogik, 1(1), 50-60. 